\title{
Peningkatan Soft Skills pada Pembelajaran Tematik-Integratif Kompetensi IPA Melalui Metode Inquiry di Kelas V
}

\author{
Dwi Paryanti \\ SD Bakalan Sewon. Cepit, Panggungharjo, Sewon, Bangunharjo, Bantul, 55188, Indonesia \\ Korespondensi Penulis. Email: dwiparyanti99@ gmail.com \\ Received: 5 January 2016; Revised:9 May 2016; Accepted: 9 May 2016
}

\begin{abstract}
Abstrak
Penelitian ini bertujuan untuk untuk meningkatkan soft skills pada pembelajaran tematik integratif kompetensi IPA melalui metode inquiry pada kompetensi IPA di kelas Va SD Bakalan Bantul dan mendeskripsikan peningkatan soft skills siswa dengan pembelajaran tematik integratif melalui metode inquiry. Jenis penelitian ini adalah penelitian tindakan kelas, yang terdiri atas tiga siklus. Penelitian ini dilaksanakan di SD Bakalan Bantul pada bulan November sampai dengan Desember 2014. Objek penelitian adalah seluruh siswa kelas Va yang berjumlah 28 siswa. Data penelitian dikumpulkan melalui observasi, tes tulis, wawancara, dokumentasi, dan catatan lapangan. Hasil penelitian menunjukkan bahwa pelaksanaan pembelajaran tematik integratif dengan metode inquiry dapat meningkatkan soft skills siswa pada kompetensi IPA
\end{abstract}

Kata Kunci: soft skills, tematik-integratif, inquiry

\section{Improving Soft Skills in Integrated Thematic Science Learning Competence Through Inquiry Method in Class V}

\begin{abstract}
This study aims to increase soft skills of students in thematic integrated learning with inquiry methods and to describe the implementation of an integrated thematic learning with inquiry methods on science competence. This research is classroom action research, which consisted of three cycles. This study was conducted in SD Bakalan Bantul from November to December 2014. The objects were all students of class Va consisting of 28 students. The data were collected using observation, paper and pencil tests, interviews, documentation, and journals. The results show that the implementation of the thematic integrated learning with inquiry methods can improve students' soft skills in science competencies.
\end{abstract}

Keywords: soft skills, thematic integrated, inquiry

How to Cite: Paryanti, D. (2017). Peningkatan soft skills pada pembelajaran tematik integratif kompetensi IPA melalui metode inquiry di kelas V SD. Jurnal Prima Edukasia, 5(1), 35-46. doi:http://dx.doi.org/10.21831/jpe.v5i1.7696

Permalink/DOI: http://dx.doi.org/10.21831/jpe.v5i1.7696 
Jurnal Prima Edukasia, 5 (1), January 2017 - 36

Dwi Paryanti

\section{Pendahuluan}

Pada tahun pelajaran 2014/2015 pemerintah telah menginstruksikan kepada seluruh sekolah dasar di Indonesia agar mengimplementasikan kurikulum 2013 untuk kelas 1, 2, 4, dan 5. Dalam Permendikbud Nomor 65 tahun 2013 Tentang Standar Proses Pendidikan Dasar dan Menengah disebutkan bahwa prinsip pembelajaran yang digunakan pada kurikulum 2013 adalah pembelajaran tematik integratif dengan pendekatan scientific. Pembelajaran tematikintegratif ini memadukan beberapa kompetensi dasar dari setiap kompetensi untuk diajarkan dalam satu tema, pengembangan aspek kognitif, afektif dan psikomotorik terpadu dalam pembelajaran. Apriani \& Wangid (2015, p.2) mengemukakan bahwa pembelajaran tematikintegratif penting untuk dilaksanakan karena mampu meningkatkan soft skill dan hard skill siswa berdasarkan proses pembelajarannya yang aktif, menarik, dan bermakna. Oleh karena itu perlu perumusan tujuan yang tepat dengan memperhatikan kebutuhan siswa dan kompetensi yang sudah dimiliki oleh siswa agar keseimbangan ketiga aspek tersebut dapat tercapai. Langkah selanjutnya adalah penggunaan metode dan pendekatan yang tepat untuk mengembangkan ketiga aspek tersebut secara terpadu dan seimbang.

Pendekatan yang digunakan dalam kurikulum 2013 ini adalah pendekatan scientific yang memungkinkan siswa untuk belajar dengan menemukan sendiri suatu konsep pengetahuan dengan menggunakan langkah-langkah ilmiah, yaitu: menanya, mengamati, menalar, mencoba dan mengkomunikasikan. Pembelajaran berpusat pada siswa karena dengan pendekatan ini siswa akan mengeksplorasi pengetahuan yang berawal dari lingkungan terdekat menuju lingkup global. Pengetahuan yang telah diperoleh siswa tidak hanya sebatas menemukan saja namun siswa juga harus mengkomunikasikan secara aplikatif.

Dalam peraturan Menteri Pendidikan dan Kebudayaan nomor 65 tahun 2013 tentang standar proses disebutkan bahwa sesuai dengan Standar Kompetensi Lulusan dan Standar Isi maka prinsip pembelajaran yang digunakan salah satunya adalah peningkatan dan keseimbangan antara keterampilan fisikal (hardskills) dan keterampilan mental (softskills). Berikut gambar yang menjelaskan hal tersebut:

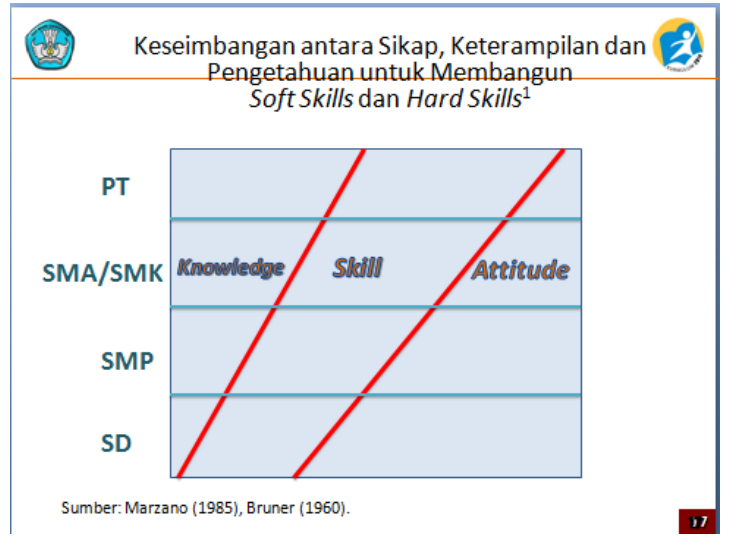

Gambar 1. Keseimbangan Soft Skills dan Hard Skills pada Setiap Jenjang Pendidikan (Sumber: Depdikbud, 2013, p.70)

Soft skills meliputi sikap dan pengetahuan sedangkan hard skills meliputi penguasaan keterampilan yang bersifat teknik. Soft skills yang dapat dikembangkan dalam contohnya keterampilan berkomunikasi, keterampilan sosial, keterampilan berfikir, dan keterampilan bekerja sama. Sedangkan hard skills contohnya teknik siswa dalam berlari, memperagakan gerakan tari, membuat prakarya dan sebagainya.

Pada kurikulum 2013 pembelajaran bersifat tematik integratif yaitu dengan memadukan beberapa kompetensi dari beberapa bidang ilmu yang dipelajari dalam satu tema. Bidang kajian Ilmu Pengetahuan Alam yang diintegrasikan dalam muatan pembelajaran Bahasa Indonesia, Matematika, Pendidikan Seni Budaya dan Prakarya, dan Pendidikan Jasmani Olahraga dan Kesehatan. Kompetensi dasar dari setiap bidang pembelajaran dipadukan dalam satu tema.

Terkait dengan bidang kajian IPA yang terpadu dalam satu tema memberikan dampak terhadap pandangan guru pada kegiatan pembelajaran yang bersifat tekstual sedangkan pada hakikatnya IPA memiliki tiga komponen, yaitu proses ilmiah, produk ilmiah, dan sikap ilmiah. Penerapan hakikat IPA dalam pembelajaran IPA merupakan tanggung jawab guru sebagai pendidik. Membelajarkan IPA kepada siswa adalah memberikan kesempatan dan bekal untuk memproses IPA dan menerapkannya dalam kehidupan sehari-hari melalui cara yang benar dan mengikuti etika keilmuwan yang berlaku dalam masyarakat. Hal ini sejalan dengan pendekatan scientific yang pada hakekatnya merupakan pendekatan mengajar yang berusaha meletakkan dasar dan mengembangkan cara berfikir ilmiah. Pendekatan ini lebih banyak menempatkan siswa untuk belajar mandiri, 
berfikir rasional, bersikap sosial, cakap berkomunikasi, mengembangkan kreativitas dan mampu memecahan masalah sehari-hari yang ada di lingkungan siswa dengan menggunakan penggunaan prinsip-prinsip atau aturan-aturan untuk mencapai tujuan yang berarti dan terbentuknya pemikiran ilmiah.

Hal pokok yang menjadi kunci utama dalam proses pembelajaran IPA adalah mambangun rasa ingin tahu siswa dan memfasilitasi siswa untuk secara aktif terlibat dalam pembelajaran sehingga rasa ingin tahu siswa dapat terjawab dengan penemuan mereka sendiri. Guru bertindak sebagai fasilitator memberikan penjelasan dan bimbingan saat memberikana jawaban kepada siswa. Guru lebih terbuka dan mendukung dengan baik setiap pertanyaan siswa untuk mengarahkan siswa dalam memahami pengetahuan.

Guru memberikan fasilitas dan bimbingan untuk siswa agar tujuan pembelajaran IPA dapat tercapai dengan baik guru diharapkan mampu merancang dan menciptakan suasana pembelajaran yang meningkatkan keterampilan siswa. Peran guru dalam kegiatan pembelajaran dan bimbingan baik di kelas maupun di luar kelas sangatlah penting karena siswa memerlukan sosok atau model yang patut dijadikan teladan siswa. Tentunya hal ini perlu diikuti dengan kemampuan seorang guru sebagai penggali dan pengembang potensi yang ada dalam diri siswa. Guru diharapkan dapat memahami potensi-potensi yang ada dalam diri siswa untuk dikembangkan dan diarahkan sebagai bekal hidup siswa. Oleh karena itu seorang guru harus mampu menganalisa situasi dan permasalahanpermasalahan yang ada dalam diri siswa.

Salah satu metode yang dapat digunakan dalam pembelajaran IPA dan sesuai dengan pendekatan scientific adalah metode inquiry. Level metode inquiry yang digunakan pada jenjang sekolah dasar adalah structured inquiry (penyelidikan terstruktur). Banch \& Bell (2008, pp.26-27) mengemukakan bahwa penyelidikan terstruktur dianggap sebagai inkuiri tingkat lebih rendah, hal itu sangat umum pada kurikulum ilmu dasar. Zion \& Mendelovici (2012, p.383) menambahkan bahwa penyelidikan terstruktur adalah pada proses penyelidikan linear yang dimulai dengan mengidentifikasi pertanyaan terkait, melalui pengumpulan data, dan berakhir dengan membuat kesimpulan berdasarkan bukti yang sesuai.

Metode inquiry dengan level stuctured inquiry diawali dengan suatu persoalan yang diangkat oleh guru yang sedemikian rupa sehingga dapat merangsang anak untuk bertanya, karena rasa ingin tahu inilah kemudian dikembangkan penyelidiakan untuk mencari jawaban tersebut Llewellyn \& Rajesh ( 2011, p.23). Dengan demikain akan melatih anak untuk bertanya, berfikir, dan mencari jawaban sesuai dengan prosedur yang benar. Selain itu dalam metode inquiry siswa berlatih bekerja sama dalam tim, mereka saling membangun pengetahuan, membentuk rasa toleransi dan menciptakan komunikasi kelompok yang interaktif. Maka dengan metode inquiry dapat memfasilitasi terbentuknya soft skills anak seperti keterampilan bertanya, berfikir, berkomunikasi, bekerja sama dengan kelompok, dan berfikir kreatif.

Guru perlu menggunakan landasan prinsip-prinsip psikologis dalam pembelajaran seperti perbedaan individual siswa dan perbedaan cara belajar siswa. Selain itu kondisi psikologis siswa yang berbeda harus menjadi perhatian guru dalam merencanakan dan mengelola sebuah pembelajaran agar memenuhi seluruh kebutuhan siswa. Karakteristik perkembangan siswa usia SD yang telah populer dikemukakan oleh Piaget adalah dalam tahapan operasional konkret/nyata. Siwa SD belum dapat berfikir abstrak seperti contohnya siswa belum bisa membayangkan bagaimana proses peredaran darah itu terjadi, maka disini perlu adanya alat peraga sebagai pembantu siswa untuk memahami konsep tersebut.

Namun berdasarkan pengamatan dan wawancara peneliti dengan guru kelas Va pada hari Sabtu tanggal 28 September 2014 pelaksanaan pembelajaran tematik integratif pada kompetensi IPA di kelas Va SD Bakalan Bantul belum berlangsung secara maksimal. Ada beberapa masalah yang terjadi dalam kelas ini, antara lain: siswa dalam berkomunikasi tidak optimal yang ditunjukkan dengan adanya beberapa siswa yang tidak menyimak penjelasan guru dan teman, siswa tidak percaya diri dalam mengemukakan pendapat atau membacakan hasil pekerjaan, rasa ingin tahu siswa yang rendah terkait dengan materi pelajaran, kesadaran diri siswa yang rendah yang ditunjukkan dengan menunda waktu pengerjaan tugas yang diberikan guru dan menganggap pekerjaan/ tugas yang diberikan tidak penting, siswa kurang menyadari bahwa teguran guru merupakan upaya penyadaran terhadap pentingya mengerjakan tugas, siswa kurang mampu menjelaskan jawaban yang terkait dengan pembelajaran yang 
sudah dijelaskan guru berulang-ulang, siswa dalam kegiatan bersosialisasi rendah yang ditunjukkan dengan sikap, tidak menghargai teman yang sedang membacakan hasil pekerjaanya di depan kelas, kepedulian siswa yang rendah, siswa kurang bertanggung jawab dengan tugas kelompoknya.

Agar masalah-masalah tersebut dapat diselesaikan maka perlu metode pembelajaran yang dapat meningkatkan keterampilan berfikir, keterampilan berkomunikasi, dan keterampilan interpersonal. Keterampilan-keterampilan tersebut sangat diperlukan siswa sebagai pondasi dasar dalam mengembangkan pengetahuan siswa pada jenjang berikutnya. Jadi siswa tak hanya pintar dengan ilmunya namun siswa juga diharapkan bagaimana caranya mereka bisa menggunakan ilmunya tanpa merendahkan orang lain, dan memanfaatkan ilmunya untuk kepentingan orang banyak.

Dari berbagai permasalahan kelas tersebut penelitian ini memfokuskan penyelesaian masalah pada masalah soft skills yang dimiliki siswa kelas VA SD Bakalan Bantul pada pembelajaran tematik integratif kompetensi IPA, Tiga aspek soft skills dalam permasalahan yaitu: kurangnya keterampilan berfikir (thinking skills), kurangnya keterampilan berkomunikasi (communication skills), dan kurangnya keterampilan interpersonal (interpersonal skills).

Beberapa fokus permasalahan di atas perlu adanya usaha untuk segera diselesaikan, penyelesaian permasalah tersebut dirumuskan dalam rumusan masalah yaitu, yang pertama bagaimanakah cara meningkatkan soft skills pada pembelajaran tematik integratif kompetensi IPA di Kelas VA SD Bakalan Bantul? Ke dua, berapa besar peningkatan setiap aspek soft skills pada pada pembelajaran tematik integratif kompetensi IPA di Kelas VA SD Bakalan Bantul?

Penelitian ini secara khusus bertujuan untuk meningkatkan kualitas pembelajaran tematik integratif pada kompetensi IPA dengan metode inquiry ditinjau dari soft skills siswa. Secara khusus penelitian ini bertujuan untuk meningkatkan soft skills siswa pada pembelajaran tematik integratif kompetensi IPA melalui metode inquiry dan mendeskripsikan berapa besar peningkatan soft skills siswa pada pembelajaran tematik integratif dengan metode inquiry.

Dari hasil penelitian tindakan kelas ini diharapkan memberikan manfaat bagi siswa, guru dan sekolah. Manfaat bagi siswa, yaitu: meningkatkan dan mengembangkan keterampil- an berfikir siswa yang ditempuh dengan proses pembelajaran tematik integratif, meningkatkan kemampuan siswa dalam berkomunikasi yang efektif, meningkatkan kemampuan interpersonal siswa, dan membantu siswa dalam memahami akan pentingya soft skills yang harus dimiliki terkait dengan soft skills yang harus dikuasai pada jenjang berikutnya, memfasilitasi siswa dalam mengembangakan kemampuankemampuan berfikirnya yang masih belum terasah, dan meningkatkan kepercayaan diri siswa karena siswa dapat bekerja sama dan berkomunikasi dengan baik.

Manfaat penelitian ini bagi guru antara lain: meningkatkan profesionalitas guru, membantu guru dalam menyelesaikan masalah yang terjadi di kelas, menumbuhkan rasa kepercayaan diri dan optimisme bahwa setiap masalahmasalah yang sering mucul dapat diselesaikan, guru akan semakin terpanggil untuk menyelesaikan masalah yang muncul dalam kelas pada khususnya maupun dalam dunia pendidikan pada umumnya, memberikan kontribusi yang positif untuk meningkatkan karier guru.

Sedangkan untuk sekolah, penelitian ini memiliki manfaat antara lain: menghasilkan lulusan yang bermutu dan memiliki soft skills sebagai modal awal pencapaian kecakapan hidup pada jenjang berikutnya, menumbuhkan budaya profesionalisme di lingkungan sekolah, memberikan inovasi dalam pendidikan, mengembangkan budaya meneliti/ melakukan tindakan kelas di lingkungan sekolah.

\section{Metode}

Jenis penelitian ini adalah penelitian tindakan kelas yang dilaksanakan dalam tiga siklus. Setiap siklus memiliki rangkaian kegiatan yang terdiri atas kegiatan perencanaan, pelaksanaan dan observasi, dan refleksi. Hasil refleksi merupakan evaluasi dari pelaksanaan yang digunakan untuk pertimbangan perbaikan pada siklus berikutnya. Penelitian tindakan kelas ini menggunakan desain Kemmis dan Mc Taggart. Berikut ini gambar desain penelitian tindakan kelas yang mengacu pada desain Kemmis dan Mc Taggart. 


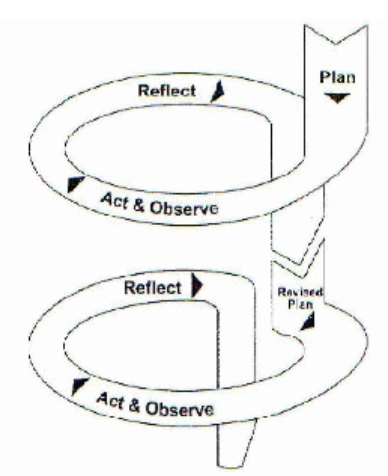

Gambar 2. Model Penelitian Kemmis dan Mc Taggart (Sumber: Mc Taggart, 1991, p.32)

Pada tahap rencana merupakan serangkaian tindakan sistematis untuk meningkatkan apa yang hendak terjadi (Sukardi, 2012, p.5). Pada perencanaan ini harus fleksibel karena segala rencana yang sudah disusun dapat berubah pada kondisi/ keadaan tertentu yang tak dapat diprediksi sebelumnya. Perencanaan lebih bersifat strategis yang mampu menjawab tantangan yang muncul dalam perubahan, dan dapat mengenal rintangan rintangan. Perencanaan dalam penelitian tindakan kelas meliputi rancangan pendekatan pembelajaran, penyusuna rancangan skenario tindakan, perencanaan penilaian dan perencanaan setting kelas.

Pada tahap tindakan adalah pelaksanaan dari rencana, dalam hal ini meliputi tindakan yang dilakukan oleh peneliti sebagai upaya membangun pemahaman konsep siswa serta mengamati hasil atau dampak dari diterapkannya metode pembelajaran inquiry. Dalam kegiatan mengamati, peneliti dan rekan sejawat yang sebagai kolaborator pengamat melakukan kegiatan mencatat dan merekam seluruh kejadian yang muncul dalam pelaksanaan pembelajaran di kelas. Hal yang diamati adalah soft skills siswa dalam mengikuti pembelajaran, kinerja guru dalam pelaksanaan pembelajaran tematik integratif dengan metode inquiry.

Pada tahap refleksi yang dilakukan peneliti adalah mengkaji, melihat dan mempertimbangkan hasil atau dampak dari tindakan yang dilakukan berdasarkan lembar pengamatan yang diisi oleh pengamat, hasil portofolio siswa, catatan anekdotorial. Refleksi ini dilakukan oleh kolaborator dengan mendiskusikan temuantemuan yang di dapat dalam observasi pelaksanaan kegiatan. Hasil temuan yang telah dikaji kemudian digunakan untuk pertimbangan rencana selanjutnya. Penelitian ini dilakukan secara kolaboratif dengan 2 teman sejawat yang masing-masing sebagai observer dan guru kelas sebagai pelaku tindakan sedangkan peneliti sebagai observer.

Penelitian ini dilaksanakan mulai bulan November sampai dengan bulan Desember 2014. Penelitian ini dilaksanakan di kelas Va SD Bakalan Bantul. Subyek penelitian adalah siswa kelas Va SD Bakalan yang berjumlah 28 siswa. yang terdiri atas 14 siswa putra dan 14 siswa putri.

Pada setiap siklus penelitian ini terdiri atas 2 kali pembelajaran. Setiap pembelajaran dilakukan observasi. Observasi ini dilakukan untuk memperoleh data hasil pelaksanaan pembelajaran tematik integratif, metode inquiry dan ketercapaian soft skills siswa.

Instrumen yang digunakan untuk observasi pelaksanaan pembelajaran tematik integratif berupa ceklist pelaksanaan pembelajaran tematik integratif. Instrumen yang digunakan untuk observasi pelaksanaan metode inquiry adalah ceklist pelaksanaan metode inquiry. Sedangkan instrumen untuk observasi soft skills siswa menggunakan skala bertingkat soft skills. Keterbatasan penginderaan observer juga perlu didukung dengan penggunaan kamera perekam/ video recorder karena dari hasil rekaman ini dapat dilihat/ diketahui hal-hal yang mungkin belum dapat diamati oleh observer. Selain itu juga digunakan catatan lapangan untuk mencatat kejadian penting atau mencolok selama pelaksanaan pembelajaran.

Pada setiap akhir siklus dilaksanakan tes tulis hasil belajar kompetensi IPA untuk aspek kognitif. Soal tes tulis kompetensi IPA ini disusun berdasarkan Kompetensi Dasar yang telah ditempuh oleh siswa selama kegiatan pembelajaran tematik integratif pada kompetensi IPA. Selain itu dilakukan penilaian antar teman dan penilaian diri siswa. Hasil penilaian diri dan antar teman ini untuk mendukung/memperkuat data hasil observasi. Sedangkan tes tulis kompetensi IPA untuk mengetahui hasil thinking skills siswa.

Pada penelitian ini akan diperoleh data kualitatif dan data kuantitatif. Data kualitatif berasal dari catatan lapangan dan dokumentasi hasil perekaman video, kemudian data tersebut dideskripsikan sesuai dengan aspek-aspek yang yang diamati, meliputi deskripsi pelaksanaan pembelajaran tematik integratif, deskripsi pelaksanaan metode inquiry, dan deskripsi perilaku siswa yang terkait dengan soft skills. Sedangkan data kuantitatif diperoleh dari hasil observasi dan tes kompetensi IPA. Data kuantitatif dianalisis secara statistik deskriptif 
dengan menghitung rata-rata nilai hasil belajar, modus, nilai tertinggi, dan nilai terendah kemudian disajikan dalam bentuk tabel dan grafik dari hasil tes kompetensi IPA. Data dalam bentuk persentase dideskripsikan dan diambil kesimpulan tentang masing-masing komponen dan indikator berdasarkan kriteria yang ditentukan.

Kriteria keberhasilan untuk penelitian tindakan kelas ini antara lain: pelaksanaan pembelajaran tematik integratif mencapai kriteria baik, pelaksanaan metode inquiry mencapai kategori baik, aspek soft skills mencapai kategori baik, lebih dari atau sama dengan $75 \%$ siswa mencapai soft skills kategori baik atau baik sekali, lebih dari atau sama dengan $80 \%$ siswa telah mencapai KKM (Kriteria Ketuntasan Minimal) pada pelaksanaan tes tulis pada kompetensi IPA. Nilai KKM adalah 75. Jika seluruh kriteria keberhasilan itu tercapai maka pelaksanaan penelitian dihentikan.

\section{Hasil dan Pembahasan}

Pembelajaran tematik integratif kompetensi IPA dengan metode inquiry telah dilaksanakan di kelas V A SD Bakalan Bantul dengan tujuan untuk meningkatkan soft skills siswa pada kompetensi Ilmu pengetahuan Alam. Metode inquiry yang digunakan dalam pembelajaran ini adalah inquiry tersetruktur (structured inquiry). Pelaksanaan pembelajaran tematik integratif kompetensi IPA dengan metode inquiry dari siklus 1 sampai 3 diperoleh data yang dimuat pada Tabel 1.

Tabel 1. Pelaksanaan Pembelajaran Tematik Integratif dan Metode Inquiry

\begin{tabular}{|c|c|c|c|c|}
\hline Siklus & $\begin{array}{c}\text { Pembelajaran } \\
\text { Tematik }\end{array}$ & Kriteria & Metode & Kriteria \\
\hline & Integratif & & & \\
\hline Siklus 1 & $95 \%$ & $\begin{array}{c}\text { Sangat } \\
\text { Baik }\end{array}$ & $93 \%$ & $\begin{array}{c}\text { Sangat } \\
\text { Baik }\end{array}$ \\
\hline Siklus 2 & $98 \%$ & $\begin{array}{c}\text { Sangat } \\
\text { Baik }\end{array}$ & $97 \%$ & $\begin{array}{c}\text { Sangat } \\
\text { Baik }\end{array}$ \\
\hline Siklus 3 & $98 \%$ & $\begin{array}{c}\text { Sangat } \\
\text { Baik }\end{array}$ & $98 \%$ & $\begin{array}{c}\text { Sangat } \\
\text { Baik }\end{array}$ \\
\hline
\end{tabular}

Dari Tabel 1 tampak bahwa pada siklus 1 pelaksanaan pembelajaran tematik integratif mencapai $95 \%$ termasuk dalam kriteria baik sekali dan pelaksanaan metode inquiry mencapi 93\% termasuk dalam kriteria baik sekali. Perbaikan pembelajaran terus diupayakan. Sehingga pada siklus 2 pelaksanaan pembelajaran tematik integratif mencapai $98 \%$ dan pelaksanaan metode inquiry mencapai 97\%. Pada siklus 3 pelaksanaan pembelajaran mencapai 98\% dan pelaksanaan metode inquiry mencapai $98 \%$.

Sedangkan dari hasil perhitungan setiap aspek soft skills diperoleh data yang dimuat dalam Tabel 2. Dari Tabel 2 tampak bahwa setiap skor aspek soft skills mengalami peningkatan pada setiap siklus dan mendukung peningkatan soft skills siswa pada setiap siklus pembelajaran, maka dengan hal ini sudah memenuhi kriteria keberhasilan untuk peningkatan setiap aspek soft skills.

Tabel 2. Kriteria Soft Skills Siswa pada Setiap Aspek

\begin{tabular}{cccc}
\hline \multirow{2}{*}{ Aspek Soft Skills } & \multicolumn{3}{c}{$\begin{array}{c}\text { Skor Aspek Soft Skills } \\
\text { dan Kriteria }\end{array}$} \\
\cline { 2 - 4 } & Siklus 1 & Siklus 2 & Siklus 3 \\
\hline \multirow{2}{*}{ Thinking Skills } & 643 & 660 & 739 \\
Commmunication & (Baik) & (Baik) & (Baik) \\
Skills & (Cukup) & (Baik) & (Baik) \\
Interpersonal & 275 & 285 & 312 \\
Skills & (Cukup) & (Cukup) & (Baik) \\
\hline
\end{tabular}

Structured inquiry memiliki potensi tidak hanya untuk meningkatkan pengetahuan siswa, namun juga dukungan soft skill. Soft skills dalam hal ini adalah belajar bagaimana bekerja di dalam tim, bagaimana untuk berdiskusi, bagaimana menangani materi, dan bagaimana mengatur prosedur dan percaya pada kemampuan sendiri (Schmid \& Bogner, 2014, pp. 8-9).

Peningkatan aspek thinking skill, pada siklus pertama aspek thinking skills memperoleh skor 643 dan kemudian meningkat menjadi 660 pada siklus 2. Peningkatan ini terus terjadi hingga siklus 3 mencapai skor 739 atau termasuk dalam kategori baik.

Peningkatan aspek communication skills, ada aspek communication skill perolehan skor setiap siklus mengalami peningkatan. Pada siklus 1 memperoleh skor 337 yang masih termasuk dalam kategori cukup, pada siklus 2 meningkat menjadi 389 yang sudah termasuk dalam kategori baik, dan pada siklus 3 memperoleh skor 406 yang termasuk dalam kategori baik. Pada siklus 1 aspek ini memang belum mencapai kategori baik namun terus mengalami peningkatan sampai dengan siklus 2 dan 3 mencapai kriteria baik. Hal ini karena upaya guru dalam meningkatkan keterampilan berbicara siswa pada saat berdiskusi maupun saat presentasi dari siklus pertama hingga ketiga. Pada saat diskusi guru membimbing setiap kelompok secara berkeliling tanpa memberikan intervensi 


\section{Jurnal Prima Edukasia, 5 (1), January 2017 - 41}

Dwi Paryanti

yang lebih pada kelompok, dengan hal ini guru dapat mudah berinteraksi dengan kelompok dan meningkatkan komunikasi kelompok. Menurut Sudjana (2009, p.54) pendekatan inquiry dapat dilaksanakan dengan baik jika memenuhi salah satu syarat yaitu adanya kebebasan siswa untuk berpendapat, berkarya, berdiskusi, partisipasi setiap siswa dalam setiap kegiatan belajar, guru tidak banyak campur tangan dan intervensi terhadap kegiatan belajar siswa

Siswa juga tidak segan bertanya kepada guru maupun siswa didalam kelompok untuk mengklarifikasi hal-hal yang belum mereka ketahui. Siswa kelas Va yang berada dalam rentang usia 10-11 tahun sudah dapat menyesuaikan isi pembicaraan. Pada penyesuaian ini siswa akan berusaha memahami isi pembicaraan didalam kelompok. Hal ini sesuai yang dikemukan oleh Sonnenschein (dalam Shaffer \& Kipp, 2010, p.419):

"six- to ten-year olds do provide longer messages to unfamiliar than to familiar listeners, but only the 9- and 10-year-olds among them adjusted the content of their communications to the listeners' needs by providing richer differentiating information to an unfamiliar listener".

Anak usia enam sampai sepuluh tahun memberikan pesan lebih panjang untuk orang asing daripada pendengar yang sudah dikenal, tetapi hanya pada usia 9 dan 10 tahun di antara mereka menyesuaikan isi komunikasi mereka kepada kebutuhan pendengar dengan memberikan informasi yang kaya perbedaan untuk pendengar asing. Selain itu guru dalam hal ini juga mengajarkan kepada anak agar menjadi pendengar yang baik saat teman lain berpendapat. Mengacu pada pendapat Feldman (2012, p.247) untuk meningkatkan kompetensi sosial anak antara lain adalah "Teach listening skills to children. Show them how to listen carefully and respond to the underlying meaning of a communication as well as its overt content." Ajarkan mendengarkan keterampilan untuk anak-anak. Tunjukkan mereka bagaimana untuk mendengarkan dengan seksama dan menanggapi makna yang mendasari komunikasi sebagai serta konten terbukanya. Terkait dengan pentingnya mengajarkan keterampilan berkomunikasi Gooden \& Kearns (2013, p.1) mengemukakan bahwa sejak usia dini, keluarga dan guru yang responsif sangat penting untuk memperkaya stimulasi keterampilan komunikasi anak-anak.

Selain itu pada siklus ke 2 guru juga telah mengupayakan agar siswa menunjukkan bukti hasil penyelidikannya untuk memperkuat hasil penemuannya. Llewellyn \& Rajesh (2011, p.28) mengemukakan bahwa "during these arguments, other students will be encouraged to pose counterclaims and consider alternative evidence and explanations. Throughout this process, students will gain a realistic view of the nature of science and develop proficiencies in reasoning and communication".

Selama argumen ini, siswa lain akan didorong untuk memberikan sanggahan dan mempertimbangkan bukti dan penjelasan alternatif. Sepanjang proses ini, siswa akan mendapatkan pandangan yang realistis tentang sifat ilmu dan mengembangkan kemahiran dalam penalaran dan komunikasi. Jadi dengan menunjukkan bukti hasil penemuannya siswa akan belajar dalam mengemukakan alasan yang realistis sehingga mendukung perkembangan keterampilan berfikir siswa dalam memberikan alasan yang realistis. Selain itu cara siswa dalam memberikan sanggahan ini akan meningkatkan keterampilan berkomunikasi.

Pada aspek interpersonal skill mengalami peningkatan pada setiap siklus. Pada siklus 1 memperoleh skor 275 kemudian pada siklus 2 meningkat menjadi 285 dan pada siklus 3 menjadi 312. Pada ketiga siklus ini aspek interpersonal skill termasuk dalam kategori baik. Terkait dengan peningkatan aspek interpersonal skills pelaksanaan pembelajaran pada setiap siklus untuk pengelompokan siswa selalu berubah-ubah hal ini dilakukan untuk meningkatkan penyesuaian diri dan memahami siswa lain sehingga dapat mengurangi konflik di dalam kelompok. Setiap anggota kelompok juga diberi tugas secara proporsional sehingga pada saat melakukan kerja kelompok seluruh anggota kelompok bekerja untuk hasil kelompok. Higgins dan Parson (dalam Shaffer \& Kipp, 2010, p.519)," the more experience a child has with peers, the more motivated she should be to try to understand them, and the more practiced she should become at appraising the causes of their behavior". Semakin banyak pengalaman seorang anak yang dimiliki dengan rekan-rekan, semakin termotivasi dia harus mencoba untuk memahami mereka, dan lebih terlatih untuk menilai penyebab perilaku mereka (teman-teman mereka). 
Jurnal Prima Edukasia, 5 (1), January 2017 - 42

Dwi Paryanti

Tabel 3. Persentase Pencapain Skor pada Setiap Indikator Aspek Thinking Skills

\begin{tabular}{ccccccccc}
\hline \multirow{2}{*}{ Siklus } & \multicolumn{8}{c}{ Persentase Setiap Indikator } \\
\cline { 2 - 10 } & $\mathbf{1}$ & $\mathbf{2}$ & $\mathbf{3}$ & $\mathbf{4}$ & $\mathbf{5}$ & $\mathbf{6}$ & $\mathbf{7}$ & $\mathbf{8}$ \\
\hline 1 & $56 \%$ & $73 \%$ & $79 \%$ & $80 \%$ & $77 \%$ & $76 \%$ & $62 \%$ & $71 \%$ \\
2 & $58 \%$ & $77 \%$ & $79 \%$ & $80 \%$ & $77 \%$ & $76 \%$ & $73 \%$ & $71 \%$ \\
3 & $63 \%$ & $79 \%$ & $79 \%$ & $88 \%$ & $88 \%$ & $88 \%$ & $88 \%$ & $87 \%$ \\
\hline
\end{tabular}

Peningkatan aspek thinking skills pada setiap indikator disajikan dalam Tabel 3. Rerata tertinggi pada peningkatan indikator aspek thinking skills terjadi pada siklus 3 yaitu sebesar $8,6 \%$ sedangkan pada siklus 2 hanya meningkat sebesar 2,3\%. Peningkatan ini terjadi karena pada siklus ke-3 siswa sudah mulai terbiasa dengan pola cara berfikir secara ilmiah dengan melakukan keterampilan proses IPA: bertanya, melakukan pengamatan, mengumpulkan data, membandingkan data, mengklasifikasikan data dan membuat kesimpulan.

Membiasakan anak untuk berpikir secara ilmiah akan memudahkan anak dalam mempelajari suatu materi pembelajaran hal ini ditegaskan oleh Abruscato \& De Rosa (2010, p.6) "In order to teach scientific thinking, its helpful to identify a framework for scientific thinking that is practical and teachable". Untuk mengajarkan berpikir ilmiah, membantu anak untuk mengidentifikasi kerangka kerja untuk berpikir ilmiah yang praktis dan dapat mudah diajarkan. Pada indikator nomor 3 yaitu siswa mengumpulkan informasi dari berbagi sumber tidak mengalami peningkatan dari siklus 1 sampai 3 hal ini dikarenakan terbatasnya sumber dan media yang disediakan oleh guru dan selain itu waktu yang diperlukan untuk mendapatkan informasi dari berbagai sumber sangatlah terbatas. Sumber informasi yang tersedia antara lain lingkungan sekolah, buku paket, surat kabar, guru, teman sebaya.

Pada siklus ke-2 dan 3 guru mengupayakan agar siswa bertanya dan melakukan pengamatan. Upaya ini antara lain membiarkan anak untuk mengamati keadaan tanaman yang berbeda dengan tanaman berbeda jenis dengan kelompok lainnya, merefleksi hasil kerja siswa pada siklus sebelumnya, dan memberikan pertanyaan rangsangan yang bersifat terbuka. Bertanya adalah kunci utama dalam belajar, guru harus menciptakan suasana pembelajaran yang dapat menimbulkan rasa ingin tahu anak. Ward, et.al (2008, pp.48-50) mengemukakan bahwa dengan bertanya merupakan kunci inquiry, berguna untuk membantu siswa dalam menguasasi kompetensi selanjutnya dan untuk menyiapkan untuk mengeksplorasi dan mengobservasi suatu objek menggunakan seluruh inderanya. Jadi bertanya merupakan pondasi awal untuk membangun rasa ingin tahu, dengan bertanya anak akan mampu menyelidiki hal-hal yang belum ia ketahui dengan menggunakan seluruh panca inderanya sehingga keterampilan berikutnya seperti membandingkan, mengklasifikasi, memberikan alasan dan membuat kesimpulan dapat tercapai dengan baik.

Selain karena hal tersebut, bertanya akan menciptakan interaksi sosial antara siswa dengan guru maupun siswa dengan siswa. Interaksi sosial semacam ini akan membantu siswa dalam meningkatkan pengetahuan siswa. Seperti yang dikemukakan Vygotsky (dalam Felman,2012, p.170), yaitu" children gradually grow intellectually and begin to function on their own because of the assistance that adult and peerpartners provide". Anak secara bertahap berkembang secara intelektual dan mulai memfungsikan dalam dirinya karena bantuan orang dewasa dan teman sebayanya. Sehingga dalam hal ini guru memfasilitasi siswa untuk membangun pengetahuan mereka yamg diawali dengan kegiatan bertanya.

Peningkatan indikator aspek communication skills ditunjukkan pada Tabel 4 berikut ini. Peningkatan tertinggi pada indikator nomor 15 atau indikator siswa mampu menyelesaikan permasalahan dalam kelompok (konflik), peningkatan sebesar $4 \%$. Pada siklus ke 2 ini secara perolahan siswa sudah mampu memahami perbedaan pada kelompok yang berbedabeda sehingga konflik dalam kelompok dapat direda/ dikurangi. Terkait dengan hal itu Leine $\&$ Munsch $(2014$, p.417) Anak-anak antara usia 6 dan 12 mulai menghargai memiliki sahabat, dan persahabatan ini lebih cenderung ditandai dengan berdasarkan komitmen untuk saling percaya. 
Tabel 4. Persentase Pencapain Skor pada Setiap Indikator Aspek Communication Skills

\begin{tabular}{cccccc}
\hline \multirow{2}{*}{ Siklus } & \multicolumn{5}{c}{ Persentase setiap Indikator } \\
\cline { 2 - 6 } & $\mathbf{9}$ & $\mathbf{1 0}$ & $\mathbf{1 1}$ & $\mathbf{1 2}$ & $\mathbf{1 3}$ \\
\hline 1 & $62 \%$ & $63 \%$ & $55 \%$ & $58 \%$ & $63 \%$ \\
2 & $68 \%$ & $74 \%$ & $67 \%$ & $69 \%$ & $68 \%$ \\
3 & $70 \%$ & $79 \%$ & $71 \%$ & $73 \%$ & $70 \%$ \\
\hline
\end{tabular}

Jadi dalam tahap ini siswa kelas Va SD sudah mampu memegang teguh prinsip persahabatan seperti rasa saling percaya, bertanggung jawab, meminta maaf jika berbuat kesalahan, dan memperbaiki jalinan persahabatan. Dengan demikian konflik-konflik yang terjadi dalam kelompok yang berbeda dapat terselesaikan. Pada aspek ini ada 8 siswa yang berada dalam kategori cukup yaitu EV, AG, AIS, ZN, SQ, SV, VK, dan YF. Sedangkan AIS DAN ZN mengalami peningkatan dari siklus 1 yang ada dalam kategori kurang menjadi cukup pada siklus ke 3. Perolehan kriteria cukup ini karena siswa kurang memperhatikan saat ada penjelasan maupun pertanyaan. Pada saat pembelajaran berlangsung AIS kurang memperhatikan hal ini ditunjukkan catatan lapangan pada siklus 2 hari Jumat 28 November 2014, bahwa ZN berbicara dengan AIS dan saat itu pula AIS menggambar di laci, saat di beri pertanyaan tentang apa yang disampaikan siswa yang presentasi namun ia tidak bisa menjawab.

Dalam menemukan jawaban dan dukungan jawaban siswa tidak hanya belajar menemukan jawaban yang tepat saja namun meraka juga dapat belajar bahwa diperlukan usaha untuk menemukan sebuah jawaban sehingga mereka dapat mamahami usaha seorang ilmuwan dalam menemukan sebuah penemuan. Hal ini ditegaskan oleh Elsteeg, J (1985, p.6) "not only will they look for and find an answer to their problem, they will also find that other scientists have grappled with such a problem, and often they may appreciate how much effort and research was required in order to find a solution". Tidak saja mereka akan mencari dan menemukan jawaban untuk masalah mereka, mereka juga akan menemukan bahwa ilmuwan lain telah bergulat dengan masalah seperti yang mereka alami, mereka dapat menghargai betapa banyak usaha dan penelitian diperlukan untuk menemukan solusi. Membiasakan siswa dengan mendengarkan pendapat, kritik, dan saran akan menjadikan siswa memiliki sikap menghargai pendapat dan hasil karya orang lain. Pada kelas Va ini memang sengaja kelompok pada setiap siklus berubah-ubah hal ini dilakukan agar siswa dapat berkomunikasi dan menghargai orang lain dalam satu kelompok (tim) yang sama ataupun berbeda kelompok.

Peningkatan indikator aspek interpersonal skills disajikan dalam Tabel 5.

Tabel 5. Persentase Pencapain Skor pada Setiap Indikator Aspek Interpersonal Skills

\begin{tabular}{ccccc}
\hline \multirow{2}{*}{ Siklus } & \multicolumn{4}{c}{ Persentase setiap Indikator } \\
\cline { 2 - 5 } & $\mathbf{1 4}$ & $\mathbf{1 5}$ & $\mathbf{1 6}$ & $\mathbf{1 7}$ \\
\hline 1 & $71 \%$ & $51 \%$ & $64 \%$ & $59 \%$ \\
2 & $73 \%$ & $55 \%$ & $67 \%$ & $60 \%$ \\
3 & $73 \%$ & $60 \%$ & $73 \%$ & $72 \%$ \\
\hline
\end{tabular}

Pada Tabel 5 memuat peningkatan indikator aspek interpersonal skill menunjukkan peningkatan indikator yang tertinggi pada indikator 17 yaitu siswa mentoleransi adanya perbedaan individu (perbedaan kemampuan akademik, jenis kelamin, latar belakang keluarga). Peningkatan ini karena juga telah mendorong dan membimbing siswa agar aktif di dalam kelompok. Perubahan anggota kelompok pada setiap siklus menjadikan siswa memahami dan menghargai perbedaan siswa lain. Pembentukan kelompok dilakukan oleh guru bukan dibentuk sendiri oleh siswa hal ini dilakukan untuk menghindari penolakan siswa. Seperti yang dikemukakan oleh Felman (2012, p.247) "Don't ask children to choose teams or groups publicly. Instead, assign children randomly: It works just as well in ensuring a distribution of abilities across groups and avoids the public embarrassment of a situation in which some children are chosen last".

Jangan meminta anak-anak untuk memilih tim atau kelompok publik. Sebaliknya, menetapkan anak-anak secara acak: Ia bekerja sama dengan baik dalam memastikan distribusi kemampuan seluruh kelompok dan menghindari malu publik situasi di mana beberapa anak dipilih terakhir. Keanggotaan kelompok merupakan hal yang penting untuk membantu proses sosialisasai anatra lain: belajar bekerja sama, belajar perilaku sosial yang baik,belajar menerima dan melaksanakan tanggung jawa, belajar bersikap sportif, belajar menyesuaikan diri dengan standar kelompok (Soetjiningsih, 2012, pp.265-266).

Guru berkeliling dan memandu siswa yang tidak aktif untuk ikut berpendapat di dalam kelompok. Mengacu pada untuk meningkatkan kompetensi sosial anak menurut Felman (2012, p.247)"Encourage social interaction. Teachers can devise ways to get children to take part in group activities". Mendorong 
interaksi sosial. Guru dapat menemukan caracara untuk mendapatkan anak-anak untuk mengambil bagian dalam kegiatan kelompok. Terkait dengan keterampilan interpersonal skills Chow, Shek-kam, Carol, (2008: 25-26) mengungkapkan dengan kerja kelompok dapat meningkatkan kepercayaan dan efisiensi siswa.

Menurut Felman (2012, p.247)" Teach listening skills to children. Show them how to listen carefully and respond to the underlying meaning of a communication as well as its overt content". Ajarkan mendengarkan keterampilan untuk anak-anak. Tunjukkan mereka bagaimana untuk mendengarkan dengan seksama dan menanggapi makna yang mendasari komunikasi sebagai serta konten terbukanya. Guru berusaha menugaskan siswa untuk mengemukakan pendapat secara terbuka yang terkait dengan materi yang dibacakan oleh siswa saat presentasi. Siswa menuliskan hal yang akan ditanyakan secara tertulis kemudian mengemukakkannya secara lisan memberikan kontribusi yang besar dalam peningkatan interpersonal skill. Saat siswa mengemukakan pendapat dan bertanya mereka saling mendengarkan secara seksama. Hal ini seperti yang dikemukakan oleh Felman (2012, p.247): "teach conversational skills, including the importance of asking questions and self-disclosure. Encourage students to use "I" statements in which they clarify their own feelings or opinions, and avoid making generalizations about others".

Ajarkan keterampilan berbicara, termasuk pentingnya mengajukan pertanyaan dan keterbukaan diri. Mendorong siswa untuk menggunakan pernyataan "saya" dalam mereka menjelaskan perasaan mereka sendiri atau pendapat, dan menghindari membuat generalisasi tentang orang lain. Jadi dalam hal ini guru sudah mengajarkan cara mengungkapkan yang baik dan sopan agar dapat diterima dengan baik oleh pendengar. Pendapat yang diungkapakan tidak menyingggung perasaan teman (tidak menunjukkan pendapat yang paling benar, atau menyanggah dengan kata-kata yang tak sopan). Pada perkembangan ilmu pengetahuan siswa diajarkan untuk berfikiran terbuka bahwa pengetahuan senantiasa selalu berubah dan berkembang dengan pembuktian/ penyelidikan yang tepat dan benar.

Dalam pembagian kelompok kerja yang selalu berubah anggotannya memungkinkan siswa untuk membentuk peraturan kelompok yang baru. Peraturan kelompok yang baru ini dapat diterima dan dilaksanakan oleh anggota kelompok untuk keberhasilan mereka dalam mencapai tujuan bersama. Batler, \& Le Monda, (2006, pp.242-243) mengemukakan bahwa dari hasil penelitian dan teori lain menunjukkan bahwa anak-anak tidak hanya menggunakan aturan eksplisit dalam bermain mereka juga mengelola sikap dan lain-lain, mereka mulai menghargai dan mematuhi aturan yang sebagian besar tak terucapkan untuk mengekspresikan dan mengendalikan emosi.

Peningkatan yang terendah pada indikator nomor 14 yaitu indikator siswa mampu menerima kritik dan saran yaitu sebesar $2 \%$ pada siklus ke 2 dari $71 \%$ pada siklus 1 menjadi $73 \%$ pada siklus 2 dan tidak mengalami peningkatan pada siklus 3 . Hal ini terjadi karena siswa sebatas mempertahankan kebenaran hasil penyelidikan kelompok mereka, namun hal ini tidak mengurangi rasa menghargai pendapat kelompok lain karena situasi ini dapat diatasi oleh kelompok, berdasarkan hasil catatan lapangan salah satu perbedaan pendapat itu antara lain adalah: $\mathrm{ZN}$, menanggapi tentang kekerasan batang jambu bahwa batang jambu yang keras dan dapat dimanfaatkan untuk bahan bangunan. Hal ini kemudian ditanggapi oleh $\mathrm{AB}$ bahwa yang dikemukanan $\mathrm{ZN}$ tersebut tidak sesuai dengan hal yang dibahas. Karena yang dibahas adalah tentang ciri batang basah dan tidak basah bukan kegunaan batang. FH sebagai salah satu anggota kelompok AA menanggapi tentang pertanyaan SL yang bertanya tentang penggolongan batang serai pada kelompok AA. Pertanyaan SL mengapa kelompok AA tidak menggolongkan tanaman serai. Kelompok AA masih ragu karena tanaman serai berserat apakah itu kayu atau bukan namun mengapa juga ada airnya. Hal ini diperjelas oleh VK bahwa tanaman serai termasuk berbatang basah hal ini dibuktikan dengan cara yang dilakukan YF tadi.

Jadi berdasarkan petikan catatan lapangan bahwa siswa tidak langsung menerima pendapat begitu saja namun mereka juga dapat membuktikan kebenaran hasil penyelidikan mereka. Sehingga dalam hal ini masih dalam kategori peneimaan pendapat yang baik. Pembelajaran tematik integratif dengan metode inquiry dapat meningkatkan soft skills pada siswa kelas Va SD Bakalan Bantul. Waktu pencapaian kriteria baik pada setiap aspek soft skills tidak sama. Pada aspek thinking skills kriteria baik dicapai pada siklus 1. Pada aspek communication skills dicapai pada siklus 2 dan pencapaian kriteria baik pada aspek interper- 
sonal skills dicapai pada siklus 3. Peningkatan aspek communication skills dan interpersonal skills memerlukan waktu lebih lama dari pada aspek thinking skills.

\section{Simpulan dan Saran}

Hasil penelitian menunjukkan bahwa pelaksanaan pembelajaran tematik integratif dengan metode inquiry dapat meningkatkan soft skills siswa pada kompetensi IPA. Peningkatan soft skills pada siklus pertama hingga siklus ke tiga ditunjukkan dengan peningkatan aspek soft skills. Pada aspek thingking skills siklus 1 mencapai skor 643 atau dalam ketegori baik pada siklus 2 menjadi 660 atau naik sebesar $2 \%$ dan pada siklus 3 mencapai skor 739 atau naik sebesar $8 \%$. Pada aspek communication skill siklus 1 mencapai skor 337 atau mencapai kategori cukup, pada siklus 2 mencapai skor 389 atau naik 9\% dan pada siklus 3 mencapai skor 406 atau naik sebesar $4 \%$. dan mencapai kriteria baik. Pada aspek interpersonal skills siklus 1 skor mencapai 275 atau mencapai kategori cukup, pada siklus 2 mencapai 285 atau naik sebesar $3 \%$ dan pada siklus 3 mencapai skor 312 atau naik sebesar $6 \%$ dan mencapai kriteria baik. Rata-rata nilai tes setiap akhir siklus pada kompetensi IPA aspek kognitif juga mengalami peningkatan, yaitu sebesar 78 pada siklus 1, pada siklus 2 meningkat menjadi 82, dan pada siklus 3 mencapai 84 .

Dengan memperhatikan hasil penelitian, pembahasan dan keterbatasan penelitian, peneliti memberikan saran kepada beberapa pihak. Pertama kepada pihak sekolah, yaitu: penggunaan pendekatan tematik integratif dalam kurikulum 2013 ini hendaknya menjadi salah satu alternatif dalam penggunaan pendekatan pembelajaran meskipun penggunaan kurikulum 2013 sudah tidak diwajibkan untuk SD non piloting, sekolah memberikan fasilitas untuk guru dalam melaksanakan evaluasi pembelajaran untuk memperbaiki dan meningkatkan kualitas pembelajaran. Evaluasi pelaksanaan pembelajaran yang dilakukan dalam lingkungan internal sekolah dapat dilakukan secara kolaboratif dengan rekan sejawat, terkait dengan hal tersebut di atas sekolah perlu memiliki program yang untuk meningkatkan kualitas pembelajaran. Misalnya dengan melakukan kajian pembelajaran untuk meningkatkan kualitas pembelajaran yang dilakukan secara rutin.

Saran kedua untuk guru kelas, yaitu: perlunya mengembangkan masalah-masalah yang menantang dan menarik siswa untuk melakukan penyelidikan dan pemecahannya terjangkau oleh siswa, perlunya pemetaan setiap kompetensi dalam tujuan pembelajaran sehingga dapat diupayakan untuk melakukan peta keterkaitan antar materi dan memungkinkan untuk dilakukan pendekatan pembelajarn tematik-integratif yang efektif, guru hendaknya jangan mengabaikan ide-ide yang dikemukakan oleh siswa, siswa perlu dilibatkan dalam perencanaan pembelajaran dan evaluasi pembelajaran dengan bimbingan guru.

Kepada peneliti berikutnya, peneliti memberikan saran, antara lain: penelitian selanjutnya maka perlu menambahkan waktu pelaksanaan penelitian karena mengingat pada penelitian ini peningkatan interpersonal skills memerlukan waktu yang lama untuk mencapai kategori baik, dan soft skills merupakan unsur utama pendukung kesuksesan hard skills, oleh karena itu peneliti selanjutnya perlu mengungkap peningkatan hard skills dengan menggunakan metode inqury.

\section{Daftar Pustaka}

Abruscato, J. \& De Rosa. D.A. (2010). Teaching children science a discovery approach ( $7^{\text {th }}$ ed.). New York: Pearson

Apriani, A., \& Wangid, M. (2015). Pengaruh SSP tematik-integratif terhadap karakter disiplin dan tanggung jawab siswa kelas III SD. Jurnal Prima Edukasia, 3(1), 1225.

doi:http://dx.doi.org/10.21831/jpe.v3i1.4 061

Banchi, H. \& Bell, R. (2008) The many levels of inquiry. Journal NSTA Science and Children, Oktober 2008, 26-30

Barron, B. \& Hammond, L.D. (2008). Teaching for meaningful learning: a review of research on inquiry-based and cooperative learning. San Francisco: The George Lucas Educational Foundation

Chow, K, Shek-kam, T., Carol, C.K. (2008). Grade 4 students' development of research skills through inquiry-based learning projects. Journal School Libraries Worldwide Volume 14, Number 1, Januari 2008, 10-37

Debdikbud. (2013).Kompetensi Dasar SD/MI. Jakarta: Depdikbud

Elsteeg, J. (1985). The right question at the right time. In Wynne Harlen. Primary 


\section{Jurnal Prima Edukasia, 5 (1), January 2017 - 46 \\ Dwi Paryanti}

science: Taking the plunge. (pp. 36-46). Oxford: Heinemann Education

Feldman, R.S. (2012). Discovering the life span $\left(2^{\text {nd }} e d.\right)$. New York: Pearson

Gooden, C. \& Kearns, J. (2013). The importance of communication skills in young children. Journal HDI Research Brief Summer 2013

Liu, X. (2010). Essentials of science classroom assessment. New York: Sage

Llewllyn, D. (2011). Differenteatiated science inquiry. California: Corwin Sage Company

Llewellyn, D. \& Rajesh, H. ( 2011). Fostering argumentation skills doing what real scientists really do. Journal Science Scope (Volume 35, Number 1, p.22-28 September 2011) (Diakses melalui http://eric.ed.gov/?id=EJ944038 pada hari Senin, 4 Mei 2015)

McTaggart,R. (1991). Action research: a short modern history. Victoria: Deakin University Press

Sudjana, N. (2009). Dasar-dasar proses belajar mengajar. Bandung: Sinar Baru Algesindo
Schmid, S. \& Bogner, F.X. (2015). Effects of students' effort scores in a structured inquiry unit on long-term recall abilities of content knowledge. Education Research International, Volume 2015, Article ID 82\ 6734, 1-11

Schunk, D.H. (2012). Learning theories: an eeducational perspective $6^{\text {th }} \mathrm{ed}$. (Terjemahan Hamdiah \& Rahmat Fajar). Yogyakarta: Pustaka Pelajar.

Shaffer, D.R. \& Kipp, K. (2010). Developmental psychology: childhood and adolesce. Belmont: Wadsworth

Soetjiningsih, C.H. (2012). Perkembangan anak sejak pembuahan sampai dengan kanakkanak akhir. Jakarta: Prenada Media Group

Sukardi.(2012). Metode Penelitian Pendidikan Tindakan kelas implementasi dan pengembangannya. Jakarta: Bumi Aksara

Ward, H., Roden, J., Hewlett, C., Foreman, J. (2008). Teaching science in the primary classrom. $\left(2^{\text {nd }} e d\right.$.). New York: Sage

Zion, M. \& Mendelovici, R. (2012). Moving from structured to open inquiry: challenges and limits. Journal Science Education International. Voume $l$, Number 4, 4 Desember 2012, 383-399 